\title{
Chironomidae fauna of springs in Iceland: Assessing the ecological relevance behind Tuxen's spring classification
}

\author{
Agnes-Katharina KREILING,${ }^{1,2^{*}}$ Jón S. ÓLAFSSON,${ }^{3}$ Snæbjörn PÁLSSON, ${ }^{2}$ Bjarni K. KRISTJÁNSSON ${ }^{1}$ \\ ${ }^{1}$ Hólar University College, Department of Aquaculture and Fish Biology, Háeyri 1, 550 Sauðárkrókur; ${ }^{2}$ Department of Biology, \\ University of Iceland, Askja, Sturlugata 7, 101 Reykjavík; ${ }^{3}$ Institute for Marine and Freshwater Research, Skúlagata 4, 101 Reykjavík, \\ Iceland \\ *Corresponding author: kreiling@holar.is
}

\begin{abstract}
In 1937, S.L. Tuxen studied the animal community of hot springs in Iceland, and classified springs according to their relative temperature into cold, tepid, and hot. Eighty years after Tuxen's study, we revisited some of the hot springs in Skagafjörður, Northern Iceland. Our aim was to compare the invertebrate community of 1937 and today, and to assess the stability of hot spring habitats over the years. To test Tuxen's spring classification on an ecological basis, we furthermore collected chironomid larvae from 24 springs of a broad range of temperature, with samples taken both at the surface area of the spring and at the groundwater level. The chironomid species composition of hot springs differed from that of cold and tepid springs. Whereas Cricotopus sylvestris, Arctopelopia sp., and Procladius sp. characterised the chironomid community in Icelandic hot springs, cold and tepid springs were dominated by Eukiefferiella minor, Orthocladius frigidus and Diamesa spp. Community composition analyses and the exclusive occurrence of taxa in one of the temperature classes validated the ecological relevance of Tuxen's spring classification for the chironomid species community. Both environmental parameters and invertebrate community of Icelandic hot springs seem to be the same as 80 years ago. Although springs have the potential to provide stable habitats, they are currently under high anthropogenic pressure, and should be increasingly considered in nature conservation.
\end{abstract}

Key words: Chironomid larvae; hot springs; invertebrate diversity; groundwater; geothermal areas; water temperature.

Received: January 2018. Accepted: April 2018.

This paper was presented at the $20^{\text {th }}$ International Symposium on Chironomidae, Trento, Italy, 2-8 July 2017. Session: Ecology and Biomonitoring.

\section{INTRODUCTION}

Iceland's location on an up-welling mantle plume on the Mid-Atlantic ridge, where the Eurasian and American continental plates diverge (Sigmundsson and Sæmundsson, 2008), has promoted the formation of a high number of geothermal areas and hot spring systems throughout the island (Friðleifsson, 1979; Sæmundsson, 1979; Einarsson, 1994; Torfason, 2003). Volcanic activity has furthermore resulted in large extents of the country being covered in lava fields (Einarsson, 1994). Groundwater seeps easily through the porous lava rock, leading to the formation of a multitude of cold springs. Despite the fact that cold springs in Iceland are used by humans for water supply, they have received relatively little attention by the scientific community and only few ecological studies on cold springs in Iceland have been published to this day (Govoni et al., 2018).

Since the beginning of settlement of Iceland in the $9^{\text {th }}$ century, warm and hot springs have been used for bathing and washing. Records of hot springs used by humans can be found in the Icelandic sagas, e.g. Grettissaga. It is thus not surprising that hot spring research has a long history in Iceland. Most studies have focussed on geological and hydrological characteristics of hot springs and their classification based upon those characteristics (Schwabe, 1933; Pórarinsson, 1978; Friðleifsson, 1979), whereas biological aspects of hot springs have been less studied. Examples of the few faunistic inventories of hot spring communities in Iceland are those by Tuxen (1944) for Skagafjörður, N.-Iceland, and the Central Highlands, and bórðarson (1981) for Borgarfjörður, W.-Iceland.

Tuxen's work on hot spring animal communities has been quite influential and has been cited widely (e.g. Pritchard, 1991; Glazier, 2012). The Danish biologist Søren Ludvig Tuxen stayed at the farm Mælifell in Skagafjörður, N.-Iceland from April to July 1937, and studied the springs in that area to "find out which were actually the animals characteristic of the hot springs and what were the external factors governing their life" (Tuxen, 1944, p. 3). Tuxen classified springs based on their temperature into "cold" (below or at the annual mean air temperature, in Iceland $2-4^{\circ} \mathrm{C}$ ), "tepid" (above the annual mean air temperature but below the mean 
maximum air temperature, in Iceland $5-14^{\circ} \mathrm{C}$ ), and "hot" (above the mean maximum air temperature, in Iceland above $14^{\circ} \mathrm{C}$ ) (Tuxen, 1944). This classification does not take any biotic criteria into account, and may thus be although convenient and intuitive - not reflecting differences in community composition. As the "character animals of the absolutely hot springs" for Iceland, Tuxen listed Radix ovata [valid name today Radix balthica Linnaeus 1758] (Gastropoda, Pulmonata), Scatella thermarum [valid name today Scatella tenuicosta f. thermarum Collin 1930] (Diptera, Ephydridae), and Eucricotopus sylvestris $\mathrm{f}$. thermicola [valid name today Cricotopus sylvestris (Fabricius 1794)] (Diptera, Chironomidae, Orthocladiinae).

Global climate change models predict an increase in the mean annual global surface temperature of $1-3.5^{\circ} \mathrm{C}$ during the next 80 years, with a more pronounced warming at higher latitudes (Hughes, 2000). All terrestrial, marine, and aquatic ecosystems are likely to be or are already impacted by these temperature changes. Rare exceptions of these predictions could be groundwater-fed systems such as springs, which for the most part are independent of surface air temperatures (Holmes, 2000). Springs are considered to be stable habitats with little fluctuation in environmental parameters (van der Kamp, 1995). In a world of rapid changes in biodiversity, groundwater habitats and springs could actually represent systems little affected by global warming.

Together with climate change, changes in land and resource use such as the expansion of agricultural areas threatens natural habitats worldwide. Iceland is no exception. In the Southern lowlands of Iceland, area covered by wetlands declined by at least $77 \%$ between 1900 and 2010, while agricultural land has expanded 15fold since 1913 (Wald, 2012). Intensely farmed land shows for example a lower density of breeding waders compared to semi-natural and less intensely cultivated areas (Jóhannesdóttir, 2017). These land use changes, in addition to an increase in industry (e.g., heavy industry and fish farming) and electric production (hydro and geothermal), along with an extreme growth in tourism in Iceland over the last few years, have put an ever increasing anthropogenic pressure on the Icelandic nature. In particular, sensitive habitats such as freshwater springs and geothermal areas are under severe threat of destruction by both physical (e.g., transformation into wells and boreholes, over-use as natural bathing pools, trampling of delicate vegetation in surrounding areas, draining of wetlands for expansion of agricultural land, lowering of groundwater table) and chemical impacts (mainly as excessive nutrient input). Special protection towards spring habitats is needed, as well as simple habitat classifications that can be used for conservation. To this end, we aim to i) validate the ecological relevance of Tuxen's spring classification, and ii) compare the hot spring animal communities in Iceland between 1937 and today.

\section{METHODS}

Based on the descriptions provided in Tuxen (1944) we located and sampled two of the hot springs, Hvammkotslaug and Mælifellslaug, in Skagafjörður, NIceland (Fig. 1), whose invertebrate fauna and physical properties were studied in 1937 (Tuxen, 1944). Mælifellslaug ( $\mathrm{N} 65^{\circ} 26.557^{\prime} \mathrm{W} 019^{\circ} 20.199^{\prime}, 78 \mathrm{~m}$ asl) is a limnocrene, Hvammkotslaug ( $\mathrm{N}$ 65 26.184' W $019^{\circ} 19.205^{\prime}, 82 \mathrm{~m}$ asl) on the other hand a rheocrene. Both are situated a few kilometres apart in an agricultural area, within the boundaries of farm land and on meadows used for horse and sheep grazing, respectively.

In addition, 24 permanent springs with defined source openings were sampled in different parts of Iceland during the summers of 2015 and 2016 (Fig. 1). The sites differed in water temperature (ranging from $3.8^{\circ} \mathrm{C}$ to $48.2^{\circ} \mathrm{C}$ at the source opening), spring type (rheocrene or limnocrene), and altitude (from $6 \mathrm{~m}$ to $928 \mathrm{~m}$ above sea level). At each site, invertebrate samples were collected from two locations: One directly from the upwelling groundwater at the source opening (in the following referred to as "source" sample), using electrobugging (Lento and Morin, 2014) in combination with a driftnet of $63 \mu \mathrm{m}$ mesh size. Hereby both invertebrates floating free in the water as well as those on the substratum of the source were collected. The second sample was collected at the benthic substrate few meters downstream of the source (referred to as "surface" sample to indicate the more surface water characteristics of the location as opposed to the groundwater nature of the "source" sample), using a $0.093 \mathrm{~m}^{2}$ Surber sampler with $63 \mu \mathrm{m}$ mesh. Water temperature and $\mathrm{pH}$ were measured with a multi-probe sonde (HYDROLAB DS5).

Invertebrate samples were stored in $70 \%$ ethanol and sorted under a low power microscope. Chironomid larvae were mounted on microscope glass slides and fixed in Hoyer's mounting medium (Anderson, 1954). If chironomid number per sample exceeded 250, a subsample of 200 individuals was taken, otherwise all chironomid larvae were processed. Identification to lowest taxonomic level possible was done under a compound microscope (Leica DM4000B). For chironomid larval identifications keys by Andersen et al. (2015) and Schmid (1993) were applied.

Statistical analyses were conducted using the package vegan (Oksanen et al., 2016) in R (R Core Team, 2016). Sample size was considered through rarefaction. We tested for changes in the hot spring community of the springs Hvammkotslaug and Mælifellslaug by comparing the 
invertebrate composition in our surface samples for these sites with data provided in Tuxen (1944), using Fisher's Exact test with Monte Carlo simulation for p-values. For a few taxa (e.g., Collembola and Scatella tenuicosta f. thermarum), Tuxen indicated the number of individuals with " $\infty$ " or infinite. As this is not a value which can be included in statistical analysis we replaced it with the number " 50 " as a measure of large numbers of individuals.

To study whether Tuxen's spring classification based on temperature is ecologically relevant for Chironomidae on the genus/species level, we grouped sites following his grouping into "cold", "tepid" and "hot" and compared their chironomid community composition using adonis, an ANOVA-like permutation test implemented in the vegan $\mathrm{R}$ package (see Oksanen et al., 2016). To detect which taxa were responsible for the differences in community composition between the temperature classes, we conducted an indicator species analysis using the $\mathrm{R}$ package indicspecies (De Cáceres and Legendre, 2009). Confidence intervals (CI) were obtained after 1000 bootstraps. To display chironomid diversity in relation to temperature classes, we used Shannon Diversity Index
$\left(\mathrm{H}^{1}\right)$, Taxa number, and Evenness, while differences between the classes were tested with Kruskal-Wallis Rank Sum Test and Wilcoxon Rank Sum Test.

We furthermore performed a Nonmetric Multidimensional Scaling (using metaMDS) on the species data to see whether chironomid communities clustered in a pattern that could be explained with temperature classes of the springs.

\section{RESULTS}

We obtained a total of 30,988 invertebrate specimens belonging to 14 orders. Chironomidae larvae were the most dominant group both in terms of abundance (with a total of 16,874 specimens) and in number of taxa (19). The subfamilies Orthocladiinae and Diamesinae were by far the most abundant, represented by 12 and 2 taxa, respectively. Chironominae were represented by only two genera (Micropsectra Kieffer 1909 and Chironomus Meigen 1803), and Tanypodinae by three genera (Procladius Skuse 1889, Macropelopia Thienemann1916,

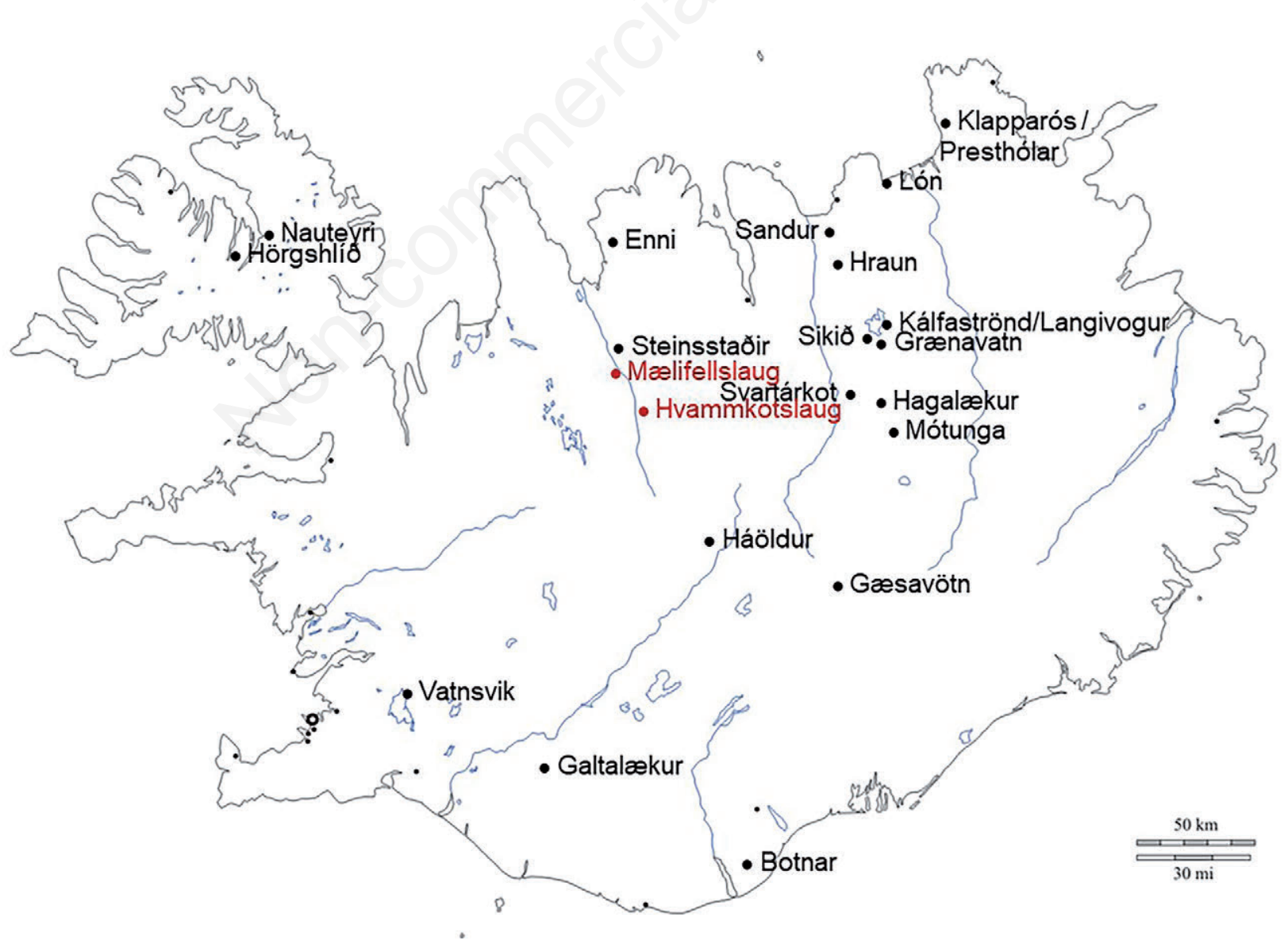

Fig. 1. Sampling sites within Iceland used in this study. The sampling sites of Tuxen (1944) revisited in this study are marked in red. 
and Arctopelopia Fittkau 1962). Overall, Eukiefferiella minor Edwards 1929, Orthocladius frigidus Zetterstedt 1838, and Diamesa spp. Meigen 1835 were the most abundant chironomid taxa in the samples (Tab. 1). Water temperature and $\mathrm{pH}$ of the springs Hvammkotslaug and
Mælifellslaug were the same as they were 80 years ago (Tab. 2). Although we found more invertebrate taxa in 2016 than Tuxen recorded, the dominating taxa were the same (Tab. 2), and all taxa reported by Tuxen were found again in 2016. For the spring Hvammkotslaug, overall

Tab. 1. Chironomid composition in Icelandic springs. Percentage of individuals of all samples collected in 2016 within the given temperature class.

\begin{tabular}{|c|c|c|c|c|}
\hline \multirow[t]{2}{*}{ Subfamily/Tribe } & \multirow[t]{2}{*}{ Species } & \multicolumn{3}{|c|}{$\%$} \\
\hline & & Cold & Tepid & Hot \\
\hline \multirow{4}{*}{ Tanypodinae } & Tanypodinae unidentified & 0 & 0.26 & 0.50 \\
\hline & Arctopelopia sp. & 0 & 0.01 & 2.11 \\
\hline & Macropelopia sp. & 0.27 & 0.26 & 2.22 \\
\hline & Procladius sp. & 0 & 0.03 & 6.04 \\
\hline \multirow[t]{2}{*}{ Diamesinae } & Diamesa sp. & 10.43 & 22.54 & 0.40 \\
\hline & Pseudodiamesa sp. & 4.70 & 0.14 & 0 \\
\hline \multirow[t]{13}{*}{ Orthocladiinae } & Chaetocladius sp. & 0.34 & 2.13 & 1.31 \\
\hline & Cricotopus sylvestris & 0.07 & 0 & 49.14 \\
\hline & Cricotopus tibialis & 0 & 0.38 & 0 \\
\hline & Eukiefferiella claripennis & 0.07 & 0 & 0 \\
\hline & Eukiefferiella minor & 11.11 & 12.40 & 0.40 \\
\hline & Heterotrissocladius sp. & 0 & 0.11 & 0 \\
\hline & Limnophyes sp. & 0 & 0.86 & 0 \\
\hline & Metriocnemus eurynotus & 0.20 & 0 & 0.40 \\
\hline & Orthocladiinae unidentified & 10.16 & 5.00 & 6.75 \\
\hline & Orthocladius frigidus & 46.69 & 46.84 & 0.30 \\
\hline & Orthocladius oblidens & 1.98 & 0.03 & 0 \\
\hline & Rheocricotopus effusus & 0.07 & 0.15 & 0 \\
\hline & Thienemanniella sp. & 6.82 & 7.90 & 0.30 \\
\hline Chironomini & Chironomus sp. & 0 & 0 & 2.01 \\
\hline Tanytarsini & Micropsectra sp. & 7.09 & 0.93 & 28.10 \\
\hline
\end{tabular}

Tab. 2. Records of invertebrate taxa and environmental parameters of the hot springs Hvammkotslaug and Mælifellslaug in Skagafjörður, N-Iceland, in 1937 and 2016. Data from 1937 retrieved from Tuxen (1944).

\begin{tabular}{|c|c|c|c|c|c|c|c|c|}
\hline \multirow[b]{2}{*}{ Spring } & \multicolumn{4}{|c|}{1937} & \multicolumn{4}{|c|}{2016} \\
\hline & Temperature & $\mathrm{pH}$ & Taxa & Individuals & Temperature & pH & Taxa & Individuals \\
\hline Hvammkotslaug & $48^{\circ} \mathrm{C}$ & $>9.0$ & $\begin{array}{l}\text { Cricotopus sylvestris } \\
\text { Scatella thermarum }\end{array}$ & $\begin{array}{l}3 \\
\infty\end{array}$ & $48.2^{\circ} \mathrm{C}$ & 9.1 & $\begin{array}{l}\text { Cricotopus sylvestris } \\
\text { Scatella thermarum } \\
\text { Diamesa sp. } \\
\text { Orthocladiinae } \\
\text { Acarina } \\
\text { Ostracoda }\end{array}$ & $\begin{array}{c}4 \\
43 \\
1 \\
1 \\
1 \\
1\end{array}$ \\
\hline Mælifellslaug & $24^{\circ} \mathrm{C}$ & $>9.0$ & $\begin{array}{l}\text { Procladius sp. } \\
\text { Copepoda } \\
\text { Gastropoda } \\
\text { Collembola }\end{array}$ & $\begin{array}{l}7 \\
2 \\
7 \\
\infty\end{array}$ & $23.2^{\circ} \mathrm{C}$ & 9.5 & $\begin{array}{l}\text { Arctopelopia sp. } \\
\text { Cricotopus sylvestris } \\
\text { Micropsectra } \text { sp. } \\
\text { Orthocladiinae } \\
\text { Procladius sp. } \\
\text { Acarina } \\
\text { Ostracoda } \\
\text { Copepoda } \\
\text { Cladocera } \\
\text { Oligochaeta } \\
\text { Gastropoda } \\
\text { Collembola }\end{array}$ & $\begin{array}{c}6 \\
65 \\
2 \\
6 \\
12 \\
16 \\
4 \\
626 \\
22 \\
139 \\
14 \\
32\end{array}$ \\
\hline
\end{tabular}


invertebrate composition at order or family level was statistically different between years, whereas chironomid composition at genus or species level was not (Invertebrate composition: Fisher's Exact test, $\mathrm{P}<0.001$. Chironomid composition: Fisher's Exact test, $\mathrm{P}=0.477$ ). For the spring Mælifellslaug, we detected differences in communities between 1937 and 2016 on both taxonomic levels (Invertebrate composition: Fisher's Exact test,
$\mathrm{P}<0.001$. Chironomid composition: Fisher's Exact test, $\mathrm{P}=0.001$ ). Excluding the taxa which had infinite numbers (presented with a number of 50), did not change those results.

After grouping our 24 spring sites based on their temperature as proposed by Tuxen (1944), we obtained eleven sites in the category "cold", six in "tepid" and seven in "hot". Differences in chironomid communities
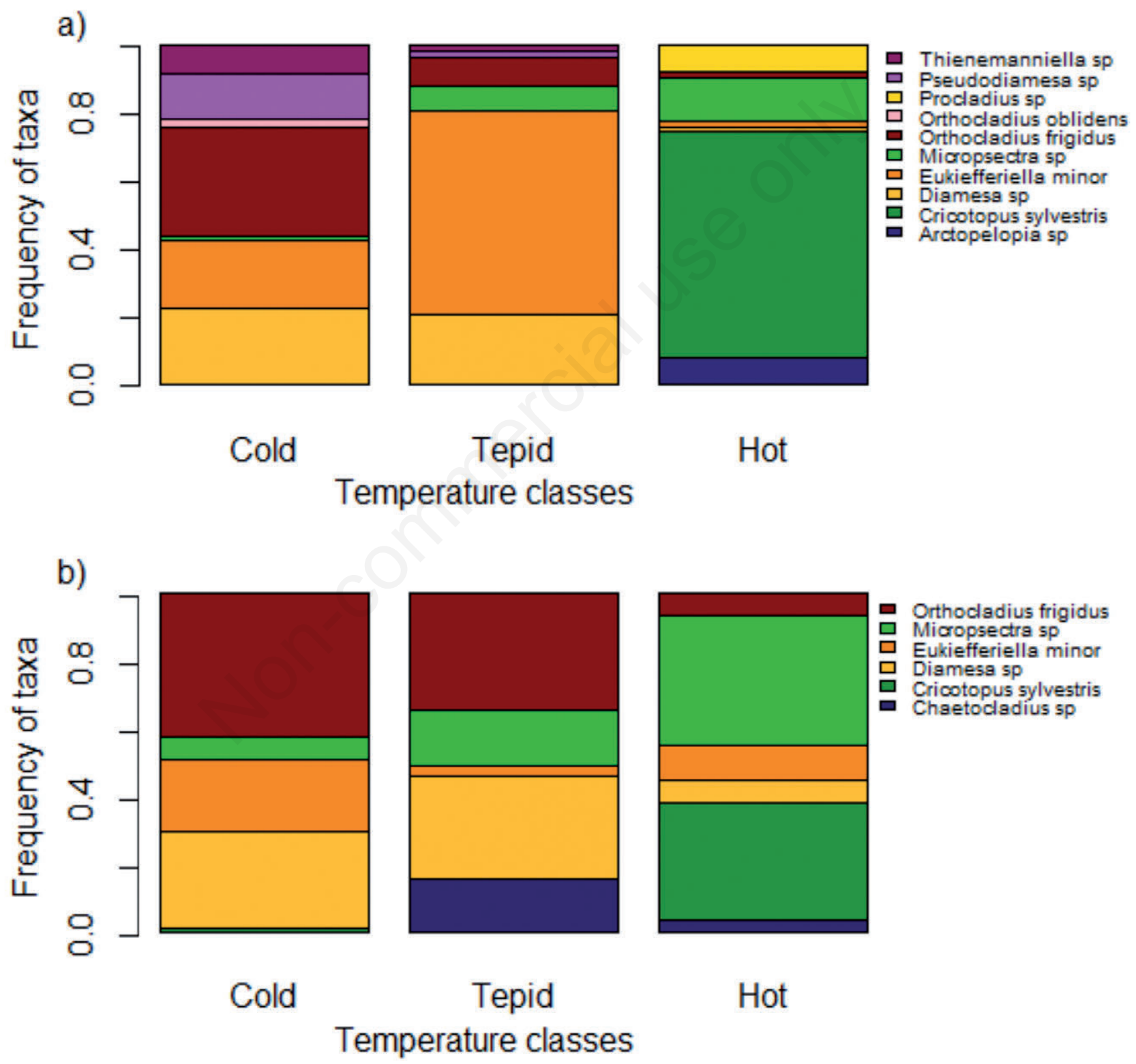

Fig. 2. Chironomid community composition of Icelandic springs in surface (a) and source samples (b). Springs are classified into cold, tepid, and hot (see section "Methods" for explanation). a) ANOVA-like permutation test (adonis), all temperature classes: F Model=4.051, $\mathrm{P}=0.001$, cold $v s$ tepid: $\mathrm{F}$ Model=0.992, $\mathrm{P}=0.426$, tepid $v s$ hot: $\mathrm{F}$ Model=5.306, $\mathrm{P}=0.002$, cold $v s$ hot: $\mathrm{F}$ Model $=6.226$, $\mathrm{P}=0.001$, after rarefaction). b) ANOVA-like permutation test (adonis), all temperature classes: $\mathrm{F}$ Model $=1.954, \mathrm{P}=0.023$, cold $v s$ tepid: $\mathrm{F}$ Model $=0.967, \mathrm{P}=0.468$, tepid $v$ s hot: $\mathrm{F}$ Model $=2.189, \mathrm{P}=0.039$, cold $v$ s hot: $\mathrm{F}$ Model=2.685, $\mathrm{P}=0.007$, after rarefaction). 
between temperature categories were highly significant for the surface samples (ANOVA-like permutation test (adonis), $\mathrm{F}$ Model=4.051, $\mathrm{P}=0.001$ ) (Fig. 2a), and also significant for the source samples (ANOVA-like permutation test (adonis), $\mathrm{F}$ Model $=1.954, \mathrm{P}=0.023$ ) (Fig. 2b). To evaluate the differences among the groups we tested all pairwise comparisons, i.e. "cold" against "tepid", "tepid" against "hot", and "cold" against "hot". At the surface, differences in the temperature classes were due to differences between "tepid" and "hot", and between "cold" and "hot", even after taking multiple comparisons into account, applying the Bonferroni correction, whereas "cold" $v s$ "tepid" was not significant (ANOVA-like permutation test (adonis): Cold $v s$ tepid: $\mathrm{F}$ Model $=0.992, \mathrm{P}=0.426$, tepid $v$ s hot: $\mathrm{F}$ Model $=5.306$, $\mathrm{P}=0.002$, cold $v$ s hot: $\mathrm{F}$ Model $=6.226, \mathrm{P}=0.001$ ). A similar pattern was found for the source, with differences between "tepid" and "hot", and between "cold" and "hot" (ANOVA-like permutation test (adonis), cold $v$ s tepid: F
Model $=0.967, \mathrm{P}=0.468$, tepid $v s$ hot: $\mathrm{F}$ Model $=2.189$, $\mathrm{P}=0.039$, cold $v$ sot: $\mathrm{F}$ Model $=2.685, \mathrm{P}=0.007$ ).

The indicator species analysis revealed three taxa with associations with the temperature classes, in either source or surface samples. Cricotopus sylvestris was an indicator species for hot springs (Source: IndVal.g $=0.53, \mathrm{CI}=0.000$ $0.817, \mathrm{P}=0.067$. Surface: IndVal.g $=0.93, \mathrm{CI}=0.707-1.000$, $\mathrm{P}=0.005$. Fishers combined probabilities for the two sites is 0.0003$)$. Diamesa spp. Meigen 1835 was an indicator species for cold springs (Source: IndVal.g $=0.71$, $\mathrm{CI}=0.496-0.866, \quad \mathrm{P}=0.011$. Surface: IndVal.g $=0.64$, $\mathrm{CI}=0.407-0.865, \mathrm{P}$ 0.011) and tepid springs (Source: IndVal.g $=0.54, \quad \mathrm{CI}=0.295-0.762, \quad \mathrm{P}=0.011$. Surface: IndVal.g $=0.57, \quad \mathrm{CI}=0.192-0.810, \quad \mathrm{P}=0.011$. Fishers combined probabilities for the two sites at both temperature classes is 0.0001). Eukiefferiella minor Edwards 1929 associated with tepid springs at the surface (IndVal.g $=0.77, \mathrm{CI}=0.413-0.960, \mathrm{P}=0.035$ ) and with the source of cold springs (IndVal.g $=0.80, \mathrm{CI}=0.532-0.959$,

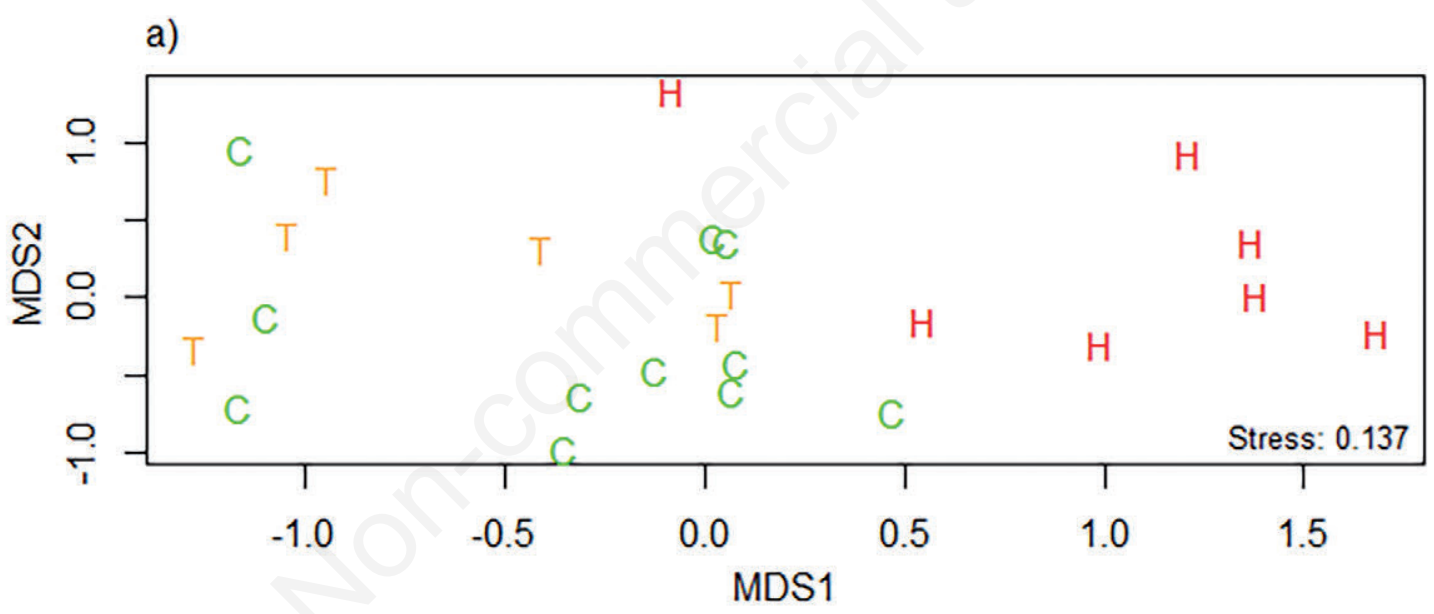

b)

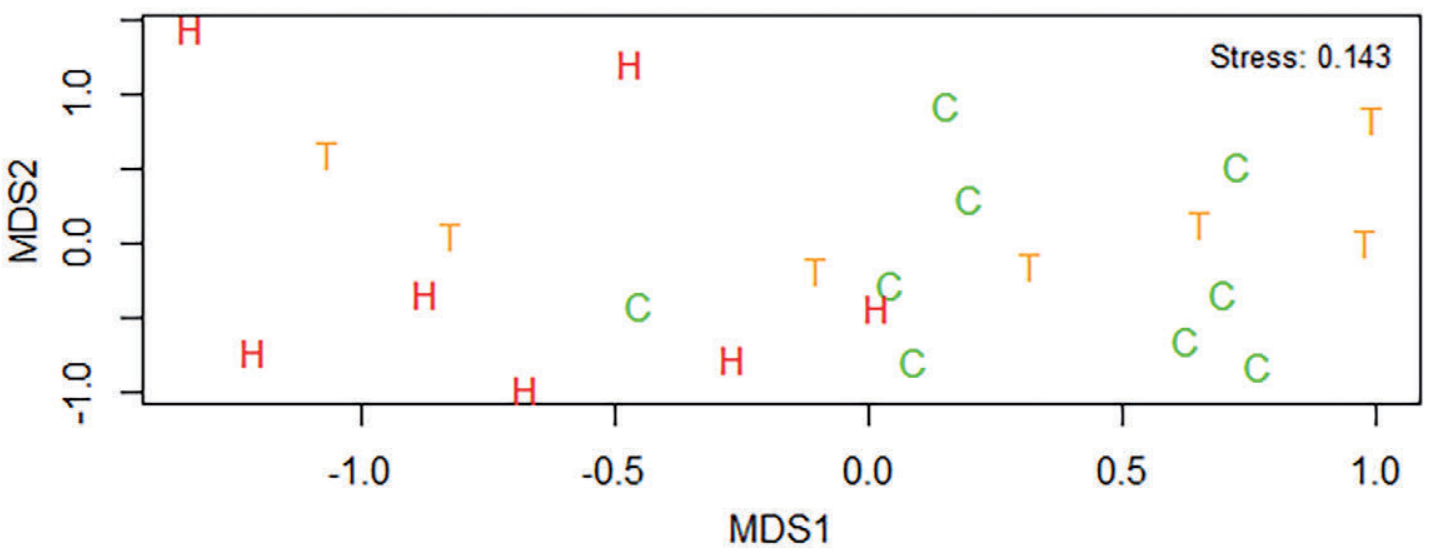

Fig. 3. Ordination of chironomid communities based on nonmetric multidimensional scaling with respect to Tuxen's classification in surface samples (a) and source samples (b). C, cold; T, tepid; H, hot. 
$\mathrm{P}=0.008$ ). Indications of associations to hot springs were furthermore found for Arctopelopia sp. and Procladius sp., to tepid springs for Chaetocladius spp., and to cold springs for Pseudodiamesa sp. and Thienemanniella sp. Kieffer 1911, but the numbers of individuals obtained for these species were small.

The metaMDS analysis showed that in the surface samples, chironomid communities were clustered according to temperature classes (Fig. 3a), with a clear separation between cold and hot springs and less clear separation for tepid springs, whose communities seemed to group within the cold spring communities. In the source samples, the pattern looked similar but the clustering of chironomid communities into spring temperature classes was less obvious (Fig. 3b).

Higher diversity (Shannon Diversity Index, $\mathrm{H}^{1}$ ) was generally observed in the tepid springs than in the cold and the hot springs at the surface, whereas the opposite was the case at the source (Fig. 4). Differences in the Shannon Diversity Index between temperature classes were significant at the surface (Kruskal-Wallis Rank Sum Test, chi-squared $=6.555, \mathrm{P}=0.038$ ) but not at the source (Kruskal-Wallis Rank Sum Test, chi-squared=2.799, $\mathrm{P}=0.247$ ). However, when we tested temperature classes in surface samples in pairwise comparison using Wilcoxon Rank Sum Test, no differences could be found. Neither Taxa number nor Evenness differed significantly between temperature classes at either source or surface.

\section{DISCUSSION}

The environmental parameters measured for the hot springs Hvammkotslaug and Mælifellslaug have not changed over the past 80 years (Tab. 2). Although all the species found by Tuxen were also found in the present study, there were statistical differences in their community composition between 1937 and 2016. This was the case both for the invertebrate community on order/family level and the chironomid community on genus/species level. However, we do not know what sampling method Tuxen applied in 1937, and how quantitative his sampling was. For Hvammkotslaug and Mælifellslaug he listed only two chironomid species, Cricotopus sylvestris (Orthocladiinae) and Procladius sp. (Tanypodinae), whereas additionally we found Arctopelopia sp. (Tanypodinae), Diamesa sp. (Diamesinae) (one individual), and Micropsectra sp. (Tanytarsini). Other

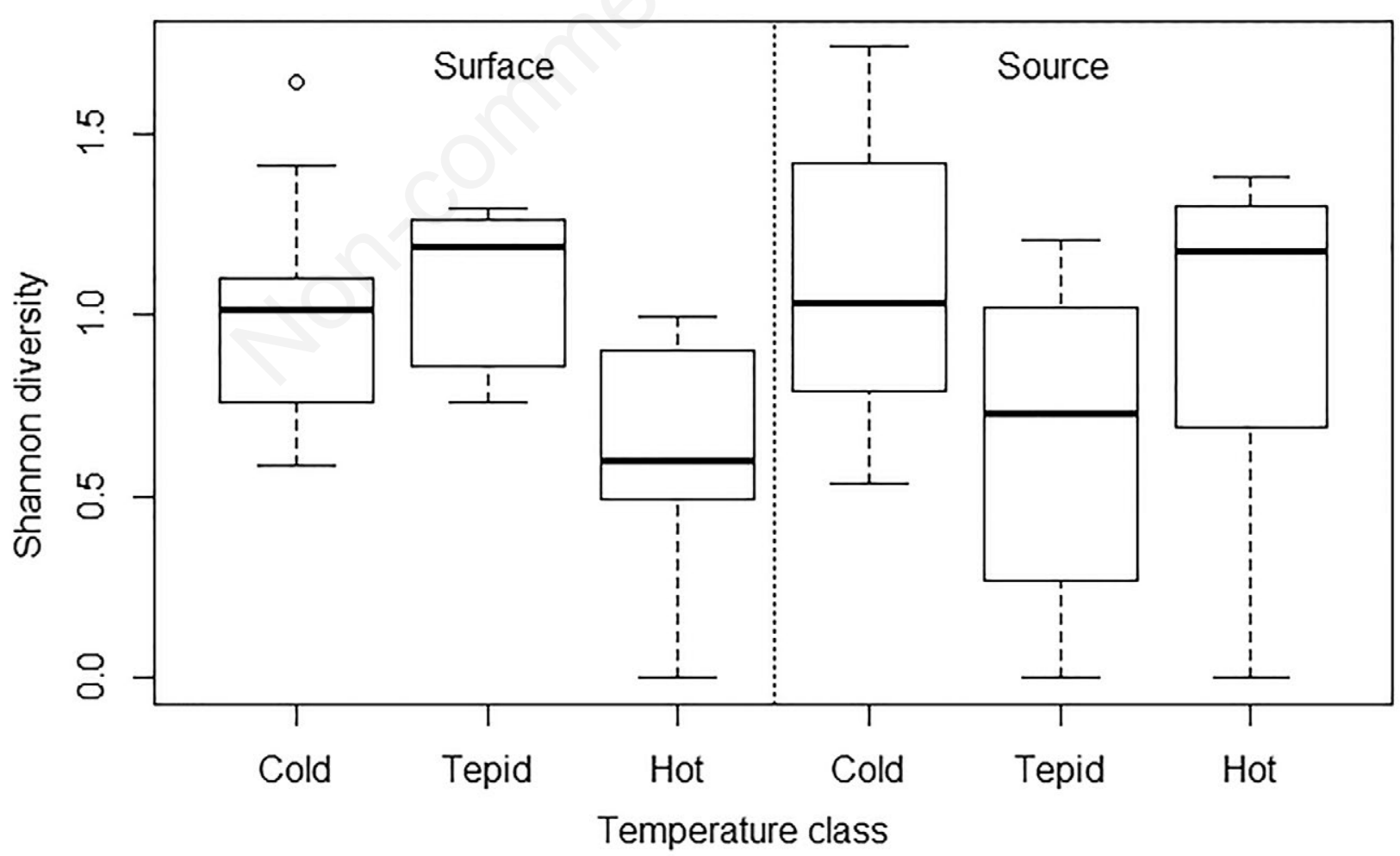

Fig. 4. Shannon diversity of chironomid communities as a function of the temperature class. Diversity differs between temperature classes at the surface but not at the source. Kruskal-Wallis Rank Sum Test, Surface: chi-squared=6.555, P=0.038, Source: chisquared $=2.799, \mathrm{P}=0.247$. 
invertebrate taxa found in 2016, but not mentioned by Tuxen (1944), were Acarina and Ostracoda for both Hvammkotslaug and Mælifellslaug, and Cladocera and Oligochaeta for Mælifellslaug. One has to be careful, though, to draw conclusions based on absence data, especially when lacking information on exact sampling methods. It may be that the four invertebrate groups found now were present at the sites in 1937 but for some reasons were not represented in the samples. However, Tuxen reported all four taxa for other springs, both cold and hot (Tuxen, 1944). Similar is the case of the chironomid taxa Arctopelopia sp. and Micropsectra sp. that were found now. Tuxen reported Micropsectra sp. for a cold spring in Skagafjörður, in close vicinity of Mælifellslaug, so we know that the genus did occur in the area in 1937. In 2016, both Arctopelopia sp. and Micropsectra sp. were found in very low numbers in Mælifellslaug, namely six and two individuals, respectively. The absence of these genera in Tuxen's samples taken from Mælifellslaug could be attributed to random variance in the samples, or else they represent a more recent colonization. Overall, it seems that hot springs may provide stable habitats over decades and that their dominant invertebrate groups have been the same during the past 80 years.

Tuxen's classification of springs according to their relative temperature is based on the mean annual air temperature of a given place (Tuxen, 1944), and the split between tepid and hot corresponds well to larger areas such as the average temperature in July both for Reykjavík, SW.-Iceland $\left(13.3^{\circ} \mathrm{C}\right)$ and Akureyri, N.Iceland $\left(14.5^{\circ} \mathrm{C}\right)$ today. We assigned our springs to Tuxen's temperature classes and compared their chironomid community composition. There are species exclusively found in one of the temperature classes (e.g., Cricotopus tibialis Meigen 1804 and Limnophyes sp. Eaton 1875 only in tepid and the rare Procladius sp. only found in hot springs; Tab. 2). Cricotopus sylvestris was found to be an indicator species for the hot springs. Diamesa spp. characterize the tepid and cold springs, and Eukiefferiella minor was found to be an indicator species for tepid springs at the surface and for cold springs at the source. It should though be noted that several species were represented in the samples in low frequencies and may give stronger associations with temperature with increased sampling. Differences in community composition were highly significant for the samples collected from the surface, but less so for the samples collected at the source openings. A plausible explanation could be that the surface community is generally more diverse than the source community, with a higher number of both species and individuals. A high number of species could promote inter-specific competition and niche partitioning along an environmental gradient (e.g., $\mathrm{pH}$, altitude, spring type, vegetation density). This could lead to a high variability in invertebrate composition among springs with respect to environmental factors such as temperature. It has been shown that spring fauna is highly individual (Erman and Erman, 1995; Lencioni et al., 2011) depending on the occurrence of different microhabitats and local environmental conditions (Bottazzi et al., 2011). As opposed to the surface community, the source community is made up of fewer, often more cold adapted species (Ólafsson et al., 2010), e.g. Orthocladius frigidus, Micropsectra sp., Eukiefferiella minor, Diamesa spp. The more uniform chironomid communities at the source compared to the surface could result from the mitigating and stabilizing influence of groundwater on the water temperature (Holmes, 2000). The invertebrate community at the source opening could experience less fluctuations in environmental variables, and therefore inter-species competition may be less dynamic and community composition might have more opportunities to stabilize as a result of competition outcome. Additionally, the source opening is generally less vegetated and often quite uniform in terms of substrate, which may result in fewer microhabitats and thus fewer potential for ecological niches. It has been suggested that competitive exclusion would reduce diversity in simple and stable habitats such as hot springs (Mitchell, 1974).

The reported differences in chironomid community composition in "cold", "tepid", and "hot" springs, seem to justify Tuxen's spring classification on an ecological basis, especially for the benthic substrate community of springs. The results of the nonmetric multidimensional scaling suggest a clear separation of sites in the temperature class "hot", but not for the temperature classes "tepid" and "cold" (Fig. 3). This separation is stronger at the surface (Fig. 3a) than at the source (Fig. $3 b)$. However, it is important to note that within the class "tepid" there were two species only found in that class. That "tepid" springs should be treated as a category on its own instead of being merged with the category "cold" can to large extent be justified by the presence of such species only found in that category. It is clear that water temperature is, although a main factor, not the only variable contributing to the community composition in springs. Factors such as pH (Bottazzi et al., 2011; Govoni et al., 2018), elevation (Lencioni et al., 2011), geographical location (Di Sabatino et al., 2003), and spring type, i.e. hydraulic conditions (Govoni et al., 2018) have been shown to influence invertebrate diversity in springs. The springs studied here inevitably differ in those factors additionally to the range in water temperatures, which makes it hard to disentangle interrelations. There have been other classification schemes put forward for hot springs in Iceland, e.g., the spring classification used by Pórðarson (1981) and based on Schwabe (1933) which 
differentiates between cold springs $\left(<14^{\circ} \mathrm{C}\right.$, kaldar lindir $)$, warm springs $\left(14^{\circ}-39^{\circ} \mathrm{C}\right.$, volgrur $)$, bathing springs $\left(30^{\circ}\right.$ $70^{\circ} \mathrm{C}$, laugar $)$, water geysers $\left(70^{\circ}-100^{\circ} \mathrm{C}\right.$, vatnshverir $)$, and steam geysers $\left(>100^{\circ} \mathrm{C}\right.$, gufuhverir) (Pórðarson, 1981). Tuxen's spring classification reflects differences in invertebrate communities of springs in more details at the colder part of the spectrum than the classification of Schwabe (1933), and is in our opinion a clear and plausible way to transfer ecological data into a message easily understandable by laymen and politicians when protection strategies have to be discussed. Keeping a spring classification as simple as possible by basing it on a single but relevant environmental factor such as temperature can be important in the context of regulations in nature conservation.

\section{CONCLUSIONS}

Here we find support for Tuxen's spring classification based on temperature as ecologically relevant for the benthic surface chironomid community of springs, with a clear separation of communities of cold, tepid and hot springs. Comparison with data on hot spring fauna in Iceland collected in 1937 reveals little to no change in both environmental conditions and species composition over the past 80 years. Although springs seem to provide stable habitats over years and decades, their invertebrate communities are not immune to changes. Ecological studies on springs and geothermal areas are necessary in order to emphasize their status as unique and sensitive habitats and consider them in nature conservation regulations.

\section{ACKNOWLEDGMENTS}

Thanks to Dan Govoni, Manon S. Guérin and Ilgin Deniz Can for assistance in the field. Special thanks to Kári H. Arnarson who helped to locate and sample Tuxen's springs in Skagafjörður. Oli "Weidenmännchen" Bechberger, Hildur Magnúsdóttir and Charles C.R. Hansen made valuable comments on a preliminary draft. The project is part of a $\mathrm{PhD}$ project and was funded by the Icelandic Research Fund (RANNÍS), grant n. 141863-051.

\section{REFERENCES}

Andersen T, Cranston PS, Epler JH, 2015. Chironomidae of the Holarctic region. Keys and diagnoses. Part I: Larvae. Entomological Society, Lund: 573 pp.

Anderson LE, 1954. Hoyer's solution as a rapid permanent mounting medium for Bryophytes. Bryologist 57:242-244.

Bottazzi E, Bruno MC, Pieri V, Di Sabatino A, Silveri L, Carolli M, Rossetti G, 2011. Spatial and seasonal distribution of invertebrates in Northern Apennine rheocrene springs. J. Limnol. 70:77-92.
De Cáceres M, Legendre P, 2009. Associations between species and groups of sites: indices and statistical inference. Ecology 90:3566-3574

Di Sabatino A, Cicolani B, Gerecke R, 2003. Biodiversity and distribution of water mites (Acari, Hydrachnidia) in spring habitats. Freshwater Biol. 48:2163-2173.

Einarsson P, 1994. Geology of Iceland. Rocks and landscape. Mál og menning, Reykjavík: 309 pp.

Erman NA, Erman DC, 1995. Spring permanence, Trichoptera species richness, and the role of drought. J. Kansas Entomol. Soc. 68:50-64.

Fridleifsson IB, 1979. Geothermal activity in Iceland. Jökull 29:47-56.

Glazier DS, 2012. Temperature affects food-chain length and macroinvertebrate species richness in spring ecosystems. Freshw. Sci. 31:575-585.

Govoni DP, Kristjánsson BK, Ólafsson JS, 2018. Spring type influences invertebrate communities at cold spring sources. Hydrobiologia 808:315-325.

Holmes RM, 2000. The importance of ground water to stream ecosystem function, p.137-148. In: J.B. Jones and P.J. Mulholland (eds.), Streams and ground waters. Academic Press, San Diego.

Hughes L, 2000. Biological consequences of global warming: is the signal already apparent? Trends Ecol. Evol.15:56-61.

Jóhannesdóttir L, 2017. Links between agricultural management and wader populations in sub-arctic landscapes. $\mathrm{PhD}$ Thesis, University of Iceland.

Lencioni V, Marziali L, Rossaro B, 2011. Diversity and distribution of chironomids (Diptera, Chironomidae) in pristine Alpine and pre-Alpine springs (Northern Italy). J. Limnol. 70(s1):106-121.

Lento J, Morin A, 2014. Filling the gaps in stream size spectra: using electroshocking to collect large macroinvertebrates. Hydrobiologia 732:1-17.

Mitchell R, 1974. The evolution of thermophily in hot springs. Quarter. Rev. Biol. 49:229-242.

Oksanen J, Blanchet FG, Friendly M, Kindt R, Legendre P, McGlinn D, Minchin PR, O'Hara RB, Simpson GL, Solymos P, Stevens MHH, Szoecs E, Wagner H, 2017. vegan: Community Ecology Package. R package version 2.4-4. Available from: https://CRAN.R-project.org/package=vegan

Ólafsson JS, Ingimundardóttir GV, Hansen I, Sigurðardóttir SG, 2010. [Smádýralíf í afrennslisvatni frá háhitasvæðunum við Kröflu, Ölkelduháls og í Miðdal í Henglinum]. [Macroinvertebrate assemblages in effluent water from the high temperature geothermal areas of Krafla, Ölkelduháls and Miðdalur in Hengill, Iceland].[Report in Icelandic with English summary]. Report no. VMST/10019. Institute of Freshwater Fisheries, Reykjavík: 64 pp.

Pritchard G, 1991. Insects in thermal springs. Mem. Entomol. Soc. Canada 155:89-106.

R Core Team, 2016. R: A language and environment for statistical computing. $\mathrm{R}$ Foundation for Statistical Computing, Vienna. Available from: www.R-project.org/

Schmid PE, 1993. A key to the larval Chironomidae and their instars from the Austrian Danube region streams and rivers. Part I: Diamesinae, Prodiamesinae and Orthocladiinae. In: Wasser und Abwasser Supplementband 3/93. Federal Institute for Water Quality, Wien: 514 pp. 
Schwabe GH, 1933.[Beobachtungen über thermische Schichtungen in Thermalgewässern auf Island].[Article in German]. Arch. Hydrobiol. 26:187-196.

Sigmundsson F, Sæmundsson K, 2008. Iceland: a window on North-Atlantic divergent plate tectonics and geologic processes. Episodes 31:92-97.

Sæmundsson K, 1979. Outline of the geology of Iceland. Jökull 29:7-28.

Torfason H, 2003. [Jarðhitakort af Íslandi og gagnasafn um jarðhita].[Report in Icelandic]. Náttúrufræðistofnun Íslands skýrsla nr. 03016.

Tuxen SL, 1944. The hot springs, their animal communities and their zoogeographical significance. In: Á. Friðriksson and
S.L. Tuxen (eds.), The Zoology of Iceland. Carlsberg-Fond, Rask-Ørsted-Fond, and Sáttmálasjóour, Copenhagen and Reykjavík.

van der Kamp G, 1995. The hydrogeology of springs in relation to the biodiversity of spring fauna: A review. J. Kansas Entomol. Soc. 68:4-17.

Pórarinsson S, 1978. [Hverir og laugar, ölkeldur og kaldavermsl á Íslandi og verndun peirra].[Article in Icelandic]. Týli 8:41-50.

Pórðarson T, 1981. [Varmalindir. Hvítársíða, Hálsasveit og innanverður Reykholtsdalur].[Report in Icelandic]. Náttúruverndarkönnun fjölrit nr. 10, Reykjavík.

Wald EC, 2012. Land use development in South Iceland 19002010. Master's Thesis, University of Iceland. 